\title{
Abundant populations of iron and manganese sequestering bacteria in coastal water
}

\author{
Mikal Heldal $^{1, *}$, Kjell Magne Fagerbakke$^{1}$, Pirjo Tuomi ${ }^{2}$, Gunnar Bratbak ${ }^{1}$ \\ ${ }^{1}$ Department of Microbiology, University of Bergen, Jahnebk. 5, N-5020 Bergen, Norway \\ ${ }^{2}$ Tvärminne Zoological Station, FIN-10900 Hanko, Finland
}

\begin{abstract}
It has recently been suggested that iron is a limiting factor for phytoplankton production in nutrient-rich seas. Here we report on a group of bacteria in coastal marine surface waters forming extensive appendages with apparently high affinity for iron and manganese (Fe-Mn bacteria). Bacteria and particles were harvested by centrifugation onto grids for Transmission Electron Microscope (TEM) $\mathrm{X}$-ray microanalysis. Four different morphotypes of $\mathrm{Fe}-\mathrm{Mn}$ bacteria were identified. The total numbers of these bacteria were at the highest in the range of $5.5 \times 10^{3}$ to $1.5 \times 10^{4} \mathrm{ml}^{-1}$ The amount of iron bound was 10 to $110 \mathrm{fg} \mathrm{cell}^{-1}$ including appendages, and the $\mathrm{Mn}$ :Fe ratio (w/w) of the metal-encrusted appendages varied between 0.37 and 5.7 In some environments the Fe content of these bacteria was equivalent to a bulk concentration of about $10 \mathrm{nM}$. The Fe and $\mathrm{Mn}$ content per unit biomass of these bacteria is 1000 to 10000 times that of most other microorganisms. These organisms may thus be important for both cycling and sedimentation of $\mathrm{Fe}$ and $\mathrm{Mn}$ in marine ecosystems and for marine productivity.
\end{abstract}

KEY WORDS: Bacteria $\cdot$ Appendage - Iron - Marine waters

\section{INTRODUCTION}

Iron is one of the most important bio-active trace metals in marine ecosystems and its role in controlling marine primary production has been emphasized (Gran 1931, Martin \& Fitzwater 1988, Martin 1992. Cullen 1995). The reason for 'high nutrient, low chlorophyll' (HNLC) ocean areas has been an intriguing question for many years. The ecumenical iron hypothesis (Morel et al. 1991) has been summarized to suggest that no single factor regulates primary production in these areas, but that grazing together with e.g. iron availability is growth controlling (see Cullen 1995 for further discussion). De Baar et al. (1995) showed that iron availability was a critical factor for phytoplankton blooms in the Southern Ocean, but did not prove that macro-nutrient and $\mathrm{CO}_{2}$ depletion was a function of iron supply (Cullen 1995). The distribution of iron in the microbial communities of surface waters is also unknown: do high affinity organisms sequester iron in amounts that leave other groups iron-limited? It has

·E-mail: mikal.heldal@im.uib.no been reported that the small dominant flora in HNLC areas is not Fe-limited, and this was hypothesized to be due to their small cell size and high affinity for iron (Miller et al. 1991). The plankton elemental composition given as molar ratios of P:Fe (normalized to P) is roughly $10^{-2}$ (Brand 1991 and references therein). These measurements may include a variety of particles of both biotic and inorganic matter, and any information on distribution of iron in various particle fractions is apparently unknown.

Loss of iron from surface water through sinking of colloidal aggregates or large particles containing iron has been suggested (Martin et al. 1994). If the sinking material has a nutrient content equivalent to the Redfield type ratio (C:N:P:Fe:Mn = 106:16:1:0.005:0.0004; Bruland et al. 1991), estimates of total production and export production (sedimentation) seemed fairly simple to achieve. The iron hypothesis, which suggests that iron is a limiting nutrient for productivity and accordingly for drawdown of carbon, has apparently been based on a Redfield ratio nutrient content (Martin et al. 1991, 1994, Watson et al. 1994). If the uptake or binding of iron is substantially higher than that given 


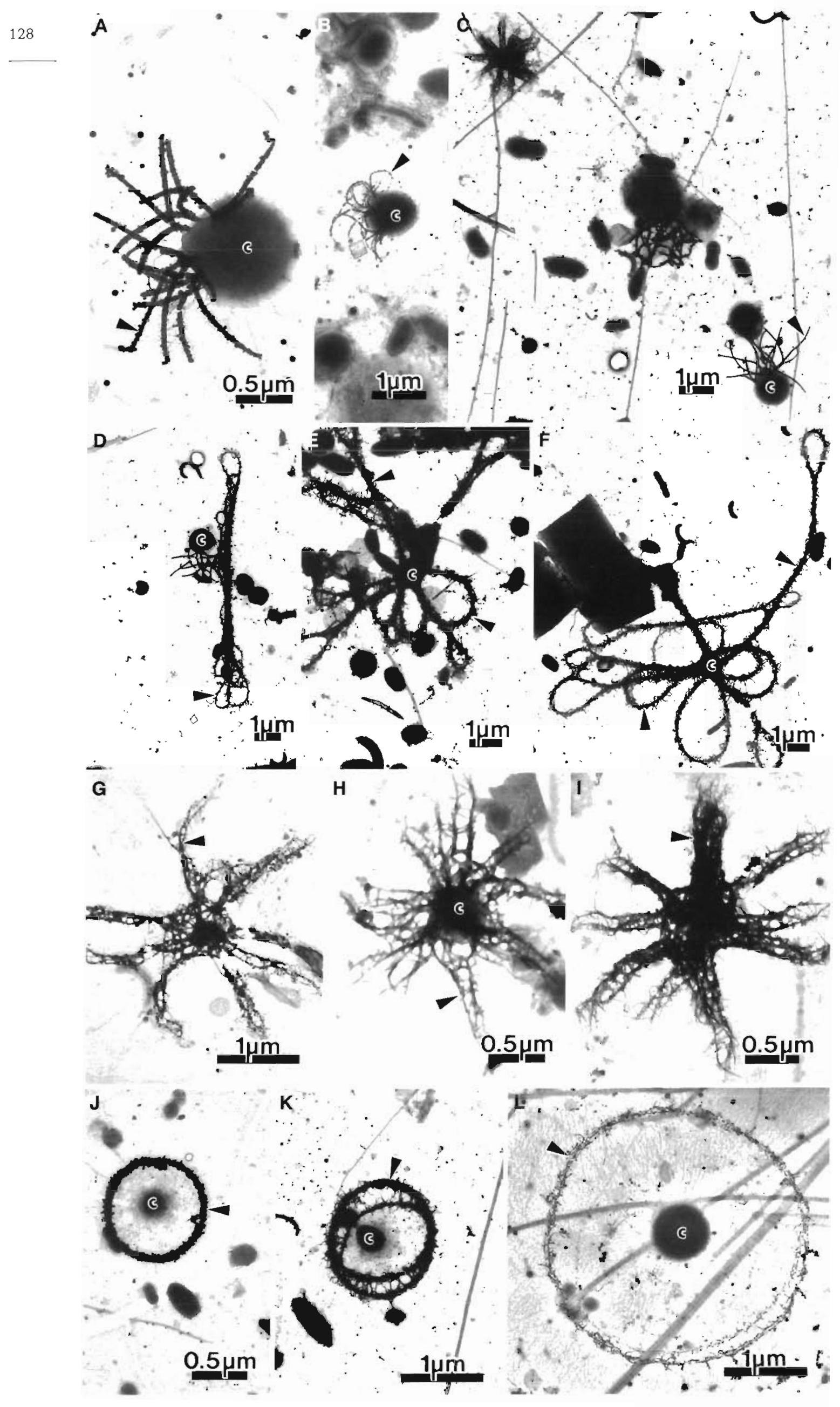


by the stoichiometry of the Redfield ratio, the export production will result in a removal of iron without concomitant removal of macronutrients and $\mathrm{CO}_{2}$.

Here we report that a relatively abundant group of bacteria in coastal waters sequesters large amounts of iron and manganese on extracellular appendages. We suggest that this selective ability among microorganisms to sequester iron may have an influence both on sedimentation of iron and on productivity in surface waters.

\section{MATERIALS AND METHODS}

Sea water was collected from Samnangerfjorden $\left(60^{\circ} 14^{\prime} \mathrm{N}, \quad 05^{\circ} 35^{\prime} \mathrm{E}\right.$, October 1992), Raunefjorden $\left(60^{\circ} 16^{\prime} \mathrm{N}, 05^{\circ} 14^{\prime} \mathrm{E}\right.$, June and October 1993), Hylsfjorden (59 $32^{\prime} \mathrm{N}, 06^{\circ} 29^{\prime} \mathrm{E}$, July 1995) in Norway; the coastal area at Tvärminne $\left(59^{\circ} 51^{\prime} \mathrm{N}, 23^{\circ} 16^{\prime} \mathrm{E}\right.$, July 1993), Finland; and Aarhus bight (Knebel Vig, June 1992), Denmark. The samples were collected from surface waters, 0 to $5 \mathrm{~m}$, and all preparations for analyses were made within $2 \mathrm{~h}$ after sampling. The cell counts were made from Transmission Electron Microscope (TEM) preparations as described elsewhere (Heldal et al. 1994).

Microorganisms and particles were harvested by centrifugation onto Al-grids supported with a carboncoated formvar film (Heldal 1993). The grids were airdried and analyzed in a JEOL 100 CX (TEM) equipped with a Tracor Z-MAX 30 X-ray detector featuring silicon crystal and Norvar single window. Neither fixatives nor stain were applied. These preparations also allow quantitative analyses of all major elements in cells except hydrogen (Norland et al. 1995).

\section{RESULTS}

The Fe-Mn bacteria included in this study (Fig 1AL. Table 1) were all from coastal surface waters ( 0 to $5 \mathrm{~m}$ ). They were discrete particles and were not associated with suspended or sinking matter. Like other bacteria, the Fe-Mn bacteria were easily seen by TEM in unfixed and unstained whole cell preparations due to their high electron density. The high electron density

Fig. 1. Electron micrographs of 4 different morphotypes of bacteria with $\mathrm{Fe}$ and $\mathrm{Mn}$ on appendages. (A-C) Group I: Fe and $\mathrm{Mn}$ on polar spines; (D-F) Group II: Fe and $\mathrm{Mn}$ on twisted wire like loops; (G-I) Group III: with Fe and $M n$ on a reticulate network forming 8 to 10 arms on the cell; $(\mathrm{J}-\mathrm{L})$ Group IV: Fe and $\mathrm{Mn}$ on an outside ring. C: cells; arrowheads: appendages containing Fe and $\mathrm{Mn}$
Table 1 Total numbers of bacteria, Fe-Mn sequestering appendage bacteria, and morphotypes at the various locations included in this study. nd: not detectable

\begin{tabular}{|c|c|c|c|}
\hline \multirow[t]{2}{*}{ Location } & \multicolumn{3}{|c|}{ Cell counts (cells $\mathrm{ml}^{-1}$ ) } \\
\hline & $\begin{array}{c}\text { Bacteria } \\
\text { (total no.) }\end{array}$ & $\begin{array}{c}\text { Fe-Mn } \\
\text { bacteria }\end{array}$ & Morphotypes ${ }^{\text {" }}$ \\
\hline Samnangerfjord & nd & $4.9 \times 10^{3}$ & II, IV \\
\hline Raunefjord & $1.2 \times 10^{6}$ & $7.4 \times 10^{3}$ & III, I, II, IV \\
\hline Hylsfjord & $0.9 \times 10^{6}$ & $1.1 \times 10^{3}$ & II \\
\hline Tvärminne & $3.4 \times 10^{6}$ & $5.5 \times 10^{3}$ & II, III \\
\hline Knebel Vig & $2.0 \times 10^{6}$ & $1.5 \times 10^{3}$ & I \\
\hline \multicolumn{4}{|c|}{ 'In order of abundance } \\
\hline
\end{tabular}

of the metal-encrusted appendages facilitated the recognition of the Fe-Mn bacteria even at low magnification, e.g. 3000x. In Fig. 2, energy spectra are shown for analyses of a whole cell (Group IIa, Table 2 ) including appendages (Fig. 2A), the grid film background (Fig. 2B), the appendage (Fig. 2C), and from part of the cell (Fig. 2D). These figures show that the Fe-Mn content of the cell is in the appendages (Fig. 2C), and the small amount of Fe-Mn in cells (Fig. 2D) is negligible and most probably from the appendage of the cell.

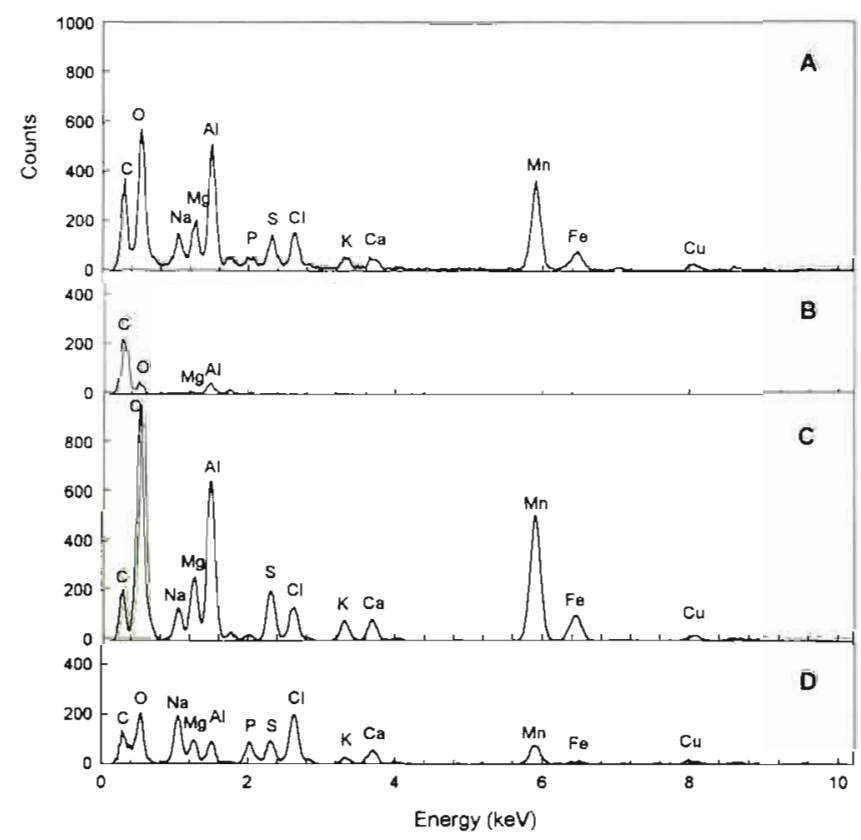

Fig. 2. X-ray analysis of a Fe-Mn bacterium from Hylsfjorden, 1995 (Group IIa, Table 2): (A) energy spectra of a whole cell including the appendages; (B) grid film background; (C) appendage; and (D) part of the cell. Mn peaks are from $K_{c 1}$ $(5.898 \mathrm{keV})$ and $\mathrm{K}_{\alpha 2}(5.887 \mathrm{keV})$; and the Fe peaks are from $M n K_{\beta 1}(6.490 \mathrm{keV})$ and $F e K_{\alpha 11}$ and $K_{\alpha 22}$ (6.403 and $6.390 \mathrm{keV}$ ). The iron signal is also evident from a small peak of the $\mathrm{Fe} K_{B 1}$ line at $7.057 \mathrm{keV}$ ( $\mathrm{A}$ and $\mathrm{C}$ ). $\mathrm{Cu}$ and $\mathrm{Al}$ peaks are from the microscope and from the grid respectively 
Table 2. Content of C, Fe and elemental ratios of N:C, P:C and Mn:Fe of cells, based on single cell analysis and including appendages, and for the cell appendages separately. n: no. of cells analysed; nd: not detectable

\begin{tabular}{|c|c|c|c|c|c|c|c|}
\hline \multirow[t]{2}{*}{ Type } & & \multicolumn{2}{|c|}{ Content (fg) } & \multicolumn{3}{|c|}{ Ratios (w:w) } & \multirow[t]{2}{*}{$\mathrm{n}$} \\
\hline & & C & $\mathrm{Fe}$ & $\mathrm{N}: \mathrm{C}$ & $P: C$ & $\mathrm{Mn}: \mathrm{Fe}$ & \\
\hline Group I & Cells ${ }^{b}$ & $84 \pm 15$ & $9 \pm 2^{\circ}$ & $0.27 \pm 0.02$ & $0.056 \pm 0.008$ & $0.8 \pm 0.2$ & 6 \\
\hline Group IIa & $\begin{array}{l}\text { Cells }+ \text { appendages } \\
\text { Appendages }\end{array}$ & $500 \pm 100$ & $50 \pm 20$ & $\begin{array}{l}0.18 \pm 0.02 \\
0.18 \pm 0.03\end{array}$ & $\begin{array}{l}0.07 \pm 0.01 \\
0.07 \pm 0.02\end{array}$ & $\begin{array}{l}5.6 \pm 1.1 \\
5.7 \pm 1.1\end{array}$ & $\begin{array}{r}10 \\
9\end{array}$ \\
\hline Group IIb & $\begin{array}{l}\text { Cells }+ \text { appendages }^{d} \\
\text { Appendages }^{d}\end{array}$ & $350 \pm 90$ & $29 \pm 5$ & $\begin{array}{l}0.28 \pm 0.03 \\
0.16 \pm 0.03\end{array}$ & $\begin{array}{l}0.039 \pm 0.005 \\
0.041 \pm 0.005\end{array}$ & $\begin{array}{l}2.5 \pm 0.4 \\
2.3 \pm 0.4\end{array}$ & $\begin{array}{l}8 \\
7\end{array}$ \\
\hline Group III & Cells + appendages ${ }^{b}$ & $150 \pm 50$ & $50 \pm 10$ & $0.20 \pm 0.03$ & $0.058 \pm 0.007$ & $0.37 \pm 0.07$ & 9 \\
\hline Group IV & $\begin{array}{l}\text { Cells }^{b} \\
\text { Cells }+ \text { appendages }{ }^{b}\end{array}$ & $\begin{aligned} 50 & \pm 20 \\
300 & \pm 140\end{aligned}$ & $\begin{array}{c}\text { nd } \\
11 \pm 40\end{array}$ & $\begin{array}{l}0.22 \pm 0.05 \\
0.10 \pm 0.04\end{array}$ & $\begin{array}{l}0.053 \pm 0.006 \\
0.031 \pm 0.001\end{array}$ & $\begin{array}{c}\text { nd } \\
0.6 \pm 0.2\end{array}$ & $\begin{array}{l}3 \\
2\end{array}$ \\
\hline
\end{tabular}

Based on the morphology of the metal-encrusted appendages, the bacteria could be assigned to 4 different groups. The Group I bacteria (Fig. $1 \mathrm{~A}-\mathrm{C}$ ) have the metals encrusted on 15 to 20 polar rod-shaped appendages at one end of the cells. The metal-encrusted rods were 1 to $2 \mu \mathrm{m}$ long and 50 to $200 \mathrm{~nm}$ wide. Selected area diffraction analysis of the appendages gave no evidence for crystalline metal deposits. In Group II (Fig. 1D-F) the appendages form wire-like twisted loops. The total lengths of the appendages were in the range of 100 to $400 \mu \mathrm{m}$. Group III bacteria (Fig. 1G-I) consisted of cells with 8 to 10 'arms' surrounding the cells. The arms were built of a reticulate network on which iron and manganese were encrusted. In Group IV bacteria (Fig. 1J-L) iron and manganese were encrusted onto a ring 1.5 to 2 cell diameters away from the cell. The cells of this group did not contain detectable amounts of iron and manganese (i.e. $<0.05 \mathrm{fg}$ ). In our unstained preparations no visible connection was seen between the cells and the ring outside, but $X$-ray microanalysis showed significant amounts of carbon in the area between the cell and the metalencrusted ring. Cells from the other groups could hardly be analyzed without interference from the appendages, as shown in Fig. 2D, where partial analysis of a Group II cell is shown. In Fig. 3 we present a more detailed study of the Group II bacteria from Hylsfjorden. The appendages of this group are loop-formed structures with 1 or 2 free ends (Fig. 3A, C, D). Cells shown in Fig. $3 \mathrm{~A}$ and $\mathrm{E}$ were from a nutrient enriched bag experiment, while the other cells shown in Fig. 3 were from open sea water. The cells of this group were pear-shaped and morphologically uniform, and occasionally dividing cells were observed (Fig. 3D, F). The metal content of the appendages varied considerably from an apparently dot wise metal-encrusting on loopforming organic material (Fig. 3E, 3F) to densely metal-encrusted loops (Fig. 3G, 3H). Appendages with uneven metal content (Figs. 2B \& 3H) on the loops were commonly seen.

The volumes of the Fe-Mn bacteria are nearly 1 order of magnitude larger than the average volumes of other bacteria $\left(0.11\right.$ to $0.31 \mu^{3}$ ) from the same locations (Fagerbakke et al. 1996).

During summer and early autumn the abundance of Fe-Mn bacteria ranged from $5.5 \times 10^{3}$ to $5 \times 10^{4} \mathrm{ml}^{-1}$ in coastal waters (Table 1). On average they constituted about $0.5 \%$ of the total bacterial numbers. The total amount of iron per cell, including appendages, was in the range of 9 to $110 \mathrm{fg}$ (Table 2), and the mean Mn:Fe ratio varied from $0.37 \pm 0.007$ to $5.7 \pm 1.1$. Variations in this ratio seemed more related to growth conditions than to differences between species. The average molar ratio for C:Fe:Mn was 30:1:1.

\section{DISCUSSION}

The evidence for the Fe-Mn bacteria reported here is based on the following: (1) the cells had bacterial size and morphology, and dividing stages have been observed for all groups; (2) the chemical composition of the cells, e.g. C:N:P ratios, and the content of diffusible ions were similar to those of other marine bacteria (Tuomi et al. 1995, Fagerbakke et al. 1996). For Group I. II and probably III organisms the metal-encrusted appendages seemed closely linked to the cell wall and even partly extended into the cell. This obscured analyses of the metal content of whole cells, but analyses of cell parts, not including any appendages, did not reveal any significant content of iron or manganese. Although the cells shown in Fig. 3 appeared morphologically similar, they may represent more than 1 species. Assuming that they represent 1 species, we may point to some mechanisms related to the formation of the metal-encrusted appendages: (1) the loops are 


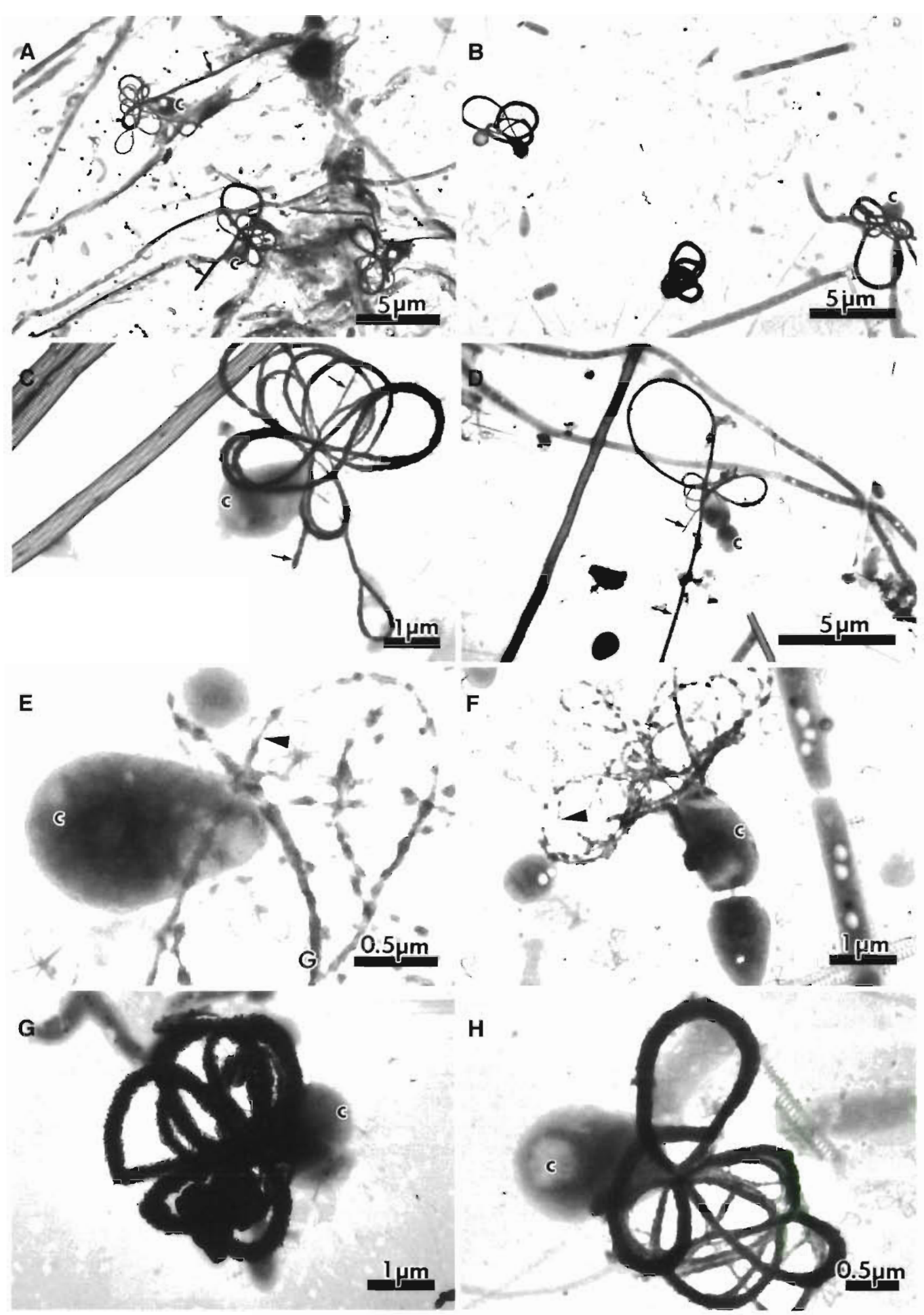

Fig. 3. Electron micrographs of Group IIa cells from Hylsfjorden, 1995. The cells were from surface water (B, C, D, F, G and H) or from bag experiments with nutrient enriched surface water ( $A$ and $E$ ). $C$; cells; arrows: free ends of appendages; arrowheads: appendages with dot wise Fe-Mn encrusting 
formed as continuous structures with 2 free ends extending from the cells (Fig 3C, D); (2) the appendages forming as loops of organic material and the metalencrusting are a secondary process (Fig. 3E, F in contrast to Fig. 3G, H); (3) no visible appendages are seen on new sibling cells (Fig. 3D, F), a fact which supports the former statement, or suggests that the formation of appendages is related to certain cell cycle stages. For the other groups of the Fe-Mn bacteria, there are also indications of the metal binding being a secondary process, after the production of appendages possessing the metal affinity. The evidence for this is from differences in electron density (Fig. 1C, B, L, K), and from $X$-ray counts of the appendages. A somewhat similar mechanism has also been described for the appendag̣ed iron bacteriuñ Gallionellâ sp. (I leldal \& Tumyi 1983). This would imply that the metal ions are not taken up and excreted by the cells, but rather passively bound to the extracellular structures.

The Group III cells (Fig, $1 \mathrm{G}-\mathrm{H}$ ) do not show any obvious bacterial morphology, but they are included on the basis of size and elemental composition, and the fact that we are not aware of any such structures belonging to other groups of organisms. For Group IV cells (Fig. 1J-L) iron and manganese encrustation was at the outer edge of an extracellular organic disc around the cells. The cells of Group IV did not contain detectable levels of iron and manganese. For the total counts at low magnification $(\times 3300$ to 8300$)$ we could only score for the metal-encrusted appendages, but during these studies we observed only a few appendages without attached cells.

From data on total counts of Fe-Mn bacteria and their metal content (Tables 1 \& 2) we estimate that this group of cells may account for up to $10 \mathrm{nM} F \mathrm{Fe}$ in Raunefjorden and Tvärminne.

Lake water bacteria of similar sizes and with iron and manganese sequestered in granules outside the cell wall have been shown to contain carboxysomes and thylacoid-like membranes, indicating their autotrophic and possibly cyanobacterial affiliation $(M$. Heldal pers. obs.). We cannot exclude the possibility that the Fe-Mn bacteria reported here are autotrophic organisms in which metal sequestration may be part of energy harvesting or detoxification of cells.

Generally we do not see any capsules or metal encrustation on marine pelagic bacteria (e.g. Borsheim et al. 1990, Fagerbakke et al. 1996). The capsule formation on bacteria may be related to several factors, and among those the availability of carbon, combined with depletion of nutrients like phosphorus or nitrogen, is important. The microbial communities in Hylsfjorden 1995 were phosphorus-limited ( $F$. Thingstad pers. comm.), but we did not observe capsules or appendages on bacteria other than those belonging to Group II
Fe and Mn deposits associated with capsulated bacteria have been reported in samples from sediment traps at 5 different Pacific Ocean stations (Cowen \& Silver 1984), from suspended particles in the water, and larger particles from sediment traps in the eastern subtropical North Pacific (Cowen \& Bruland 1985), and off the Oregon (USA) coast (Cowen 1992). Some of the bacterial capsules reported by Cowen (1992) show striking morphological similarities to the Group I and III bacteria reported in this study. In our studies of glutaraldehyde fixed samples from open ocean areas, we have not found any Fe-Mn bacteria. The most likely reason for this is that the metal-encrusted appendages seem not to be preserved in stored glutaraldehyde fixed samples (authors' unpubl. obs.)

Iligh frequencies of cells with capsules (Moriârty \& Hayward 1982), and with iron and manganese encrusted capsules (Cowen \& Silver 1984, Cowen \& Bruland 1985, Cowen 1992), have been reported for marine sediments. These results may suggest a more rapid sedimentation or higher stability of these bacteria than other non-capsulated ones, since cells with capsules are rarely seen among planktonic bacteria. It has been hypothesized that the sources of iron and manganese in sediments are from re-solubilization of metals in micro-environments with reduced $\mathrm{pE}$ (the negative logarithm of the redox potential) (Cowen \& Silver 1984, Cowen \& Bruland 1985), or from re-scavenging of metals onto marine particles in the deep water (Bruland et al. 1991). Our results show that the metals may be sequestered in oxygenated surface sea water and not solely in deep water and sediments.

Loss of iron from the production zone has been hypothesized as one possible mechanism of why nutrients were not completely consumed during the IronEx experiment: 'Iron was lost from the system due to colloidal aggregation and/or sinking of larger particles containing iron' (Martin et al. 1994). The initial concentration of nitrate was $10.8 \mu \mathrm{M}$ and by adding $4 \mathrm{nM}$ iron (Martin et al. 1994), most of the nitrate should have been consumed; and, accordingly, a reduction of $70 \mu \mathrm{M}$ carbon $(\mathrm{C}: \mathrm{N}=6.6: 1)$ should have occurred. The measured $\mathrm{CO}_{2}$ reduction was only about $7 \mu \mathrm{M}$ (Watson et al. 1994), and thus the sinking material would have a $\mathrm{N}$ :Fe ratio of 250 if sedimentation should explain the loss of iron in the IronEx experiment. For oceanic algae a C:Fe ratio of $10^{5}$ has been assumed (de Baar et al. 1995), but from the numbers given above a $C$ :Fe ratio of 1750 is estimated for sinking material.

If parts of the sedimenting biomass have molar $\mathrm{C}: \mathrm{N}$ :Fe ratios in ranges of 3:0.5:1 to $52: 13: 1$ as seen in our studies (Table 2), iron could be depleted from the surface water without any substantial drawdown of carbon and major nutrients like nitrogen and phosphorus. 
The total content of $\mathrm{C}$ and $\mathrm{N}$ of the appendages was approximately 6 times higher than that of the cells (Table 2). A few marine microorganisms have been shown to acquire iron through a siderophore-mediated uptake system (Reid \& Butler 1991). For the appendages we found a molar $\mathrm{N}: \mathrm{C}$ ratio of 0.20 , which is close to the values for some low molecular weight siderophores with high $\mathrm{Fe}^{3+}$ affinity constants. Since other transition metals are also complicated by these compounds (Butler et al. 1989), their function may be of importance for trace metal sequestration.

The information on the Fe cycle within the photic zone of marine waters is still scarce (Bruland et al. 1991), but it is reasonable to anticipate a solubilization of particulate or colloidal forms of $\mathrm{Fe}$, and a secondary sorption of Fe to a siderophore-type of compound on the bacterial appendages. As stated by Bruland et al. (1991) photoreductive dissolution of $\mathrm{Fe}$ (III) in oxides and organic material may enhance the biological availability of iron.

We suggest that the groups of Fe-Mn bacteria reported here proliferate in coastal surface waters and are responsible for a significant export of metals to the deep waters and sediments. Independent of the mechanisms of iron sequestration, the possible ecological importance of this group of organisms calls for further studies.

Acknowledgements. We thank Ole Tumyr, Department of Geology, University of Bergen for skilled help with diffraction studies, and Frede Thingstad and Svein Norland, Department of Microbiology, University of Bergen, for constructive discussions throughout this work. This work was supported by MAST-II project MEICE, contract number MAS2-CT92-0031, the EU MAST programme, contract number MAS3-CT950016 MEDEA (through Frede Thingstad to M.H., K.M.F. and G.B.\}, and by funding from Nordic Council of Ministers and Project PELAG IlI, coordinated by the Finnish Environment Agency, Finland (P.T.). The electron microscopy work was done at the Laboratory for Electron Microscopy, University of Bergen

\section{LITERATURE CITED}

Børsheim Y, Bratbak G, Heldal M (1990) Enumeration and biomass estimation of planktonic bacteria and viruses by transmission electron microscopy. Appl Environ Microbiol 56:352-356

Brand LE (1991) Minimum iron requirements of marine phytoplankton and the implications for the biogeochemical control of new production. Limnol Oceanogr 36: 1756-1771

Bruland KW, Donat JR, Hutchins DA (1991) Interactive influence of bioactive trace metals on biological production in oceanic waters. Limnol Oceanogr 36:1555-1577

Butler A, Parsons SM, Yamagata SK, de la Rosa RI (1989) Reaction of vanadate-inhibited enzymes with desferrioxamine $B$, a vanadium (V) chelator. Inorg Chim Acta 163:1-3

Cowen JP (1992) Morphological study of marine bacterial capsules: implications for marine aggregates. Mar Biol $114: 85-95$

Cowen JP, Bruland KW (1985) Metal deposits associated with bacteria: implication for Fe and Mn marine biogeochemistry. Deep Sea Res 32:253-272
Cowen JP, Silver MM (1984) The association of iron and manganese with bacteria on macroparticulate material. Science 224:1340-1342

Cullen JJ (1995) Status of the iron hypothesis after the openocean enrichment experiment. Limnol Oceanogr 40: $1336-1343$

de Baar HJW, de Jong JTM, Bakker DCE, Loscher BM, Veth C, Bathmann U, Smetacek V (1995) Importance of uron for plankton blooms and carbon dioxıde drawdown in the Southern Ocean. Nature 373:412-415

Fagerbakke KM, Heldal M, Norland S (1996) Content of carbon, nitrogen, oxygen, sulfur and phosphorus in aquatic and cultured bacteria. Aquat Microb Ecol 10:15-27

Gran HH (1931) On the conditions for the production of plankton in the sea. Rapp PV Cons Perm Int Explor Mer $75: 37-46$

Heldal M (1993) Measurement of elemental content and dry weight of single cells: X-ray microanalysis. In: Kemp PF, Sherr BF, Sherr EB, Cole JJ (eds) Handbook of methods in aquatic microbial ecology. Lewis Publishers, Boca Raton, p 387-394

Heldal M, Norland S, Bratbak G, Riemann B (1994) Determination of bacterial cell number and cell volume by means of flow cytometry, transmission electron microscopy, and epifluorescence microscopy. J Microbiol Methods 20: $255-263$

Heldal M. Tumyr O (1983) Gallionella from metalimnion in an eutrophic lake: morphology and X-ray energy-dispersive microanalysis of apical cells and stalks. Can J Microbiol 29:303-308

Martin J (1992) Iron as a limiting factor in oceanic productivity. In: Falkowski PG, Woodhead A (eds) Primary productivity and biogeochemical cycles in the sea. Plenum, New York, p 123-138

Martin JH, Fitzwater SE (1988) Iron deficiency limits phytoplankton growth in the north-east subarctic. Nature 331: $341-343$

Martin JH, Gordon RM, Fitzwater SE (1991) Iron limitation. Limnol Oceanogr 36:1973-1802

Martin JH, and 42 others (1994) Testing the iron hypothesis in ecosystems of the equatorial Pacific Ocean. Nature 371. $123-129$

Miller CB, Frost BW, Wheeler PA, Landry MR, Welschmeyer N, Powell TM (1991) Ecological dynamics in the subarctic Pacific, a possibly iron-limited ecosystem. Limnol Oceanogr 31:1600-1615

Morel FMM, Rueter JG, Price NM (1991) Iron nutrition of phytoplankton and its possible importance in the ecology of ocean regions with high nutrient and low biomass. Oceanography 4:56-61

Moriarty DJW, Hayward AC (1982) Ultrastructure of bacteria and the proportion of gram-negative bacteria in marine sediments. Microb Ecol 8:1-14

Norland S, Fagerbakke KM, Heldal M (1995) Light element analysis of individual bacteria by $\mathrm{X}$-ray microanalysis. Appl Environ Microbiol 61:1357-1362

Reid TR, Butler A (1991) Investigation of the mechanism of iron acquisition by the marine bacterium Alteromonas luteoviolaceus: characterization of siderophore production. Limnol Oceanogr 36:1738-1792

Tuomi P, Fagerbakke KM, Bratbak G, Heldal M (1995) Nutritional enrichment of a microbial community: the effects on activity, elemental composition, community structure and virus production. FEMS Microbiol Ecol 16:123-134

Watson JH, and 9 others (1994) Minimal effect of iron fertilization on sea-surface carbon dioxide concentrations. Nature 371:143-145

Manuscript first received: April 15, 1995

Revised version accepted: June 30, 1996 